\title{
DITTRICHIA GRAVEOLENS (ASTERACEAE) - A NEW ALIEN PLANT SPECIES FOR ROMANIA
}

\author{
Paul-Marian SZATMARI,2, Bogdan-Iuliu HURDU ${ }^{1}$ \\ ${ }^{1}$ Biological Research Center, 48 Republicii Street, RO-400015 Cluj-Napoca, Romania \\ ${ }^{2}$ Biological Research Center, Botanical Garden "Vasile Fati", 14 Parcului Street, RO-455200 Jibou, Romania \\ e-mail: paul.szatmari@icbcluj.ro
}

\begin{abstract}
Dittrichia graveolens (L.) W. Greuter, an invasive plant species of Mediterranean origin, is recorded for the first time in Romania. We found the species in October 2020 in two separate locations along the main highway that connects Brașov and Sibiu cities, in Southern Transylvania, central Romania. We present here the first data concerning the species occurrence in the investigated area, its observed habitat, local distribution and accompanying species. We presume that the main vector for the introduction and dispersal of this species in Romania is the high traffic density along the major roads. Dittrichia graveolens has proven its invasive potential in other regions of Europe and North America of similar temperature and precipitation regimes under an overall temperate climate. Consequently, taking into account its fast dispersal, especially in the more favourable habitats for its establishment that exist along the major roads from the lower altitudes and the riparian communities from the western, southern and eastern parts of Romania, we conclude that close monitoring of the species occurrence should be undertaken in order to better assess its full invasive potential in our country and to reduce the risk of impact on natural plant communities.
\end{abstract}

Keywords: neophyte, invasive species, Inula graveolens, dispersal pathways, disturbed habitats.

\section{Introduction}

Road networks are known to be major invasion corridors [38, 15, 39], and human-altered habitats, especially those along the roads, are important entry gates that favour the rapid establishment and dispersal of alien plant species [12, 20]. Plant invasions connected to road systems have been observed in many parts of the world [31, 56, 32, 15, 29, 51]. In Central Europe, the distribution of several alien species is linked exclusively to highways and the disturbed habitats along them (e.g., Artemisia tournefortiana, Atriplex micrantha, Cochlearia danica, Eragrostis albensis, Senecio inaequidens, Sporobolus vaginiflorus) [25, 41, 6, 7, 28, 33, 59, 19]. Other invasive species have managed to conquer all types of natural habitats, also helped by various infrastructure features like the road networks (e.g., Ambrosia artemisiifolia) [18, 30, 32].

In Romania there are many examples of alien plant species, some being recorded also on disturbed roadsides from where these plants managed to disperse further into other types of natural or semi-natural habitats adjacent to road networks (e.g., Bromus madritensis, Erigeron annuиs, Erigeron canadensis, Reynoutria japonica, Robinia pseudoacacia, Senecio inaequidens, Solidago canadensis) $[60,1,2]$. Other species, many with differing ecological requirements, have been observed mostly along roadsides, from where they sporadically spread to other areas (e.g., Galinsoga quadriradiata and Bidens frondosa in the Cerna Valley, Impatiens parviflora and Rudbeckia laciniata on the Transfăgărășan road and the Someș Valley, Cirsium candelabrum on 
the road networks crossing the western part of the Southern Carpathians, Prunus cerasifera in the NW part of Romania, personal observations). The studies made by Follak et al. [21] in several European countries concerning the alien species found along road networks are relevant also for Romania. The most problematic invasive species currently found along road verges in Europe are spreading alarmingly fast in Romania as well, along various road types related to traffic density, especially at lower altitudes, with the milder, warmer climate characterising the lowlands (e.g., Ambrosia artemisiifolia, Reynoutria japonica, Solidago canadensis, Solidago gigantea, Impatiens glandulifera, Ailanthus altissima, Robinia pseudoacacia, Acernegundo, Asclepias syriaca, Bidens frondosa, Erigeron canadensis, Erigeron annuus, Helianthus tuberosus, Impatiens parviflora, Populus $\times$ canadensis, Rudbeckia laciniata).

Dittrichia graveolens (L.) W. Greuter (syn. Inula graveolens (L.) Desf.) (Asteraceae) was formerly included in the genus Inula, from which it was separated into the genus Dittrichia, consisting of just two species, D. graveolens and D. viscosa (with three subspecies), both widely distributed in the Mediterranean Basin and both considered highly invasive in other parts of the world [11, 4, 33, 43]. It is an annual, viscid, strongly aromatic plant with a camphor-like smell, up to $20-50 \mathrm{~cm}$ tall [44]. The leaves are linear to linear-lanceolate and the ray-florets are short and yellow-coloured [35].

Its native distribution in Southern Europe includes Albania, Bosnia and Herzegovina, Croatia, Montenegro, North Macedonia, Bulgaria, France, Greece, Italy, Portugal, Serbia and Spain. Dittrichia graveolens extends its natural range also to the eastern coastlines of the Atlantic Ocean, North Africa (Algeria, Libya, Morocco, Tunisia), the Middle East and Central Asia (Afghanistan, Cyprus, Iran, Israel, Jordan, Lebanon, Pakistan, Syria, Turkey and North-West India) [11, 42, 24]. Across its natural range Dittrichia graveolens grows mainly in alluvial floodplains, riparian woodlands and margins of tidal marshes. However, in its non-native areas it occupies disturbed habitats along roadsides with ruderal vegetation, arable fields, wastelands and gravel quarries [11,36]. Outside its range it can also occur in nitrophilous communities [11].

The spread of Dittrichia graveolens in Europe outside its native range is almost exclusively connected to roads and highways, along which the species has dispersed into regions north of its native area of distribution from the Mediterranean Basin, over great distances and in a very short time (e.g., Slovakia or Poland) [33, 35]. In a separate study, it was observed that the species distribution correlates to a high degree with the highway network of the European countries [21].

In this paper we report the species Dittrichia graveolens for the first time from Romania, providing information on (1) distribution of populations and (2) local habitat conditions and then (3) discuss its invasive potential at the national scale.

\section{Material and Methods}

The field study that led to the discovery of Dittrichia graveolens in Romania was conducted during October 2020 and was included in a nationwide project (POIM120008) aimed at collecting all available distribution data regarding the alien flora and especially those plant species posing invasive potential. We recorded precise information on the locations using a handheld Garmin GPSMap 60CSx device with a $<10$ m accuracy set up in the WGS84 Geographic Coordinate System. We recorded the list of accompanying species from population 1 (Brașov County) and estimates of the covered surface and number of individuals for both populations. We 
collected herbarium specimens that were deposited in the Herbarium of "A. Borza" Botanical Garden, Babeș-Bolyai University Cluj-Napoca (CL) (Fig. 1, CL-669063 and CL-669062, Leg. et det. P.-M. Szatmari and B.-I. Hurdu, the $6^{\text {th }}$ of October 2020). The maps were developed in ArcGIS 9.3 [17]. The nomenclature follows Ball (1976) [4] and Brullo \& de Marco (2000) [11].

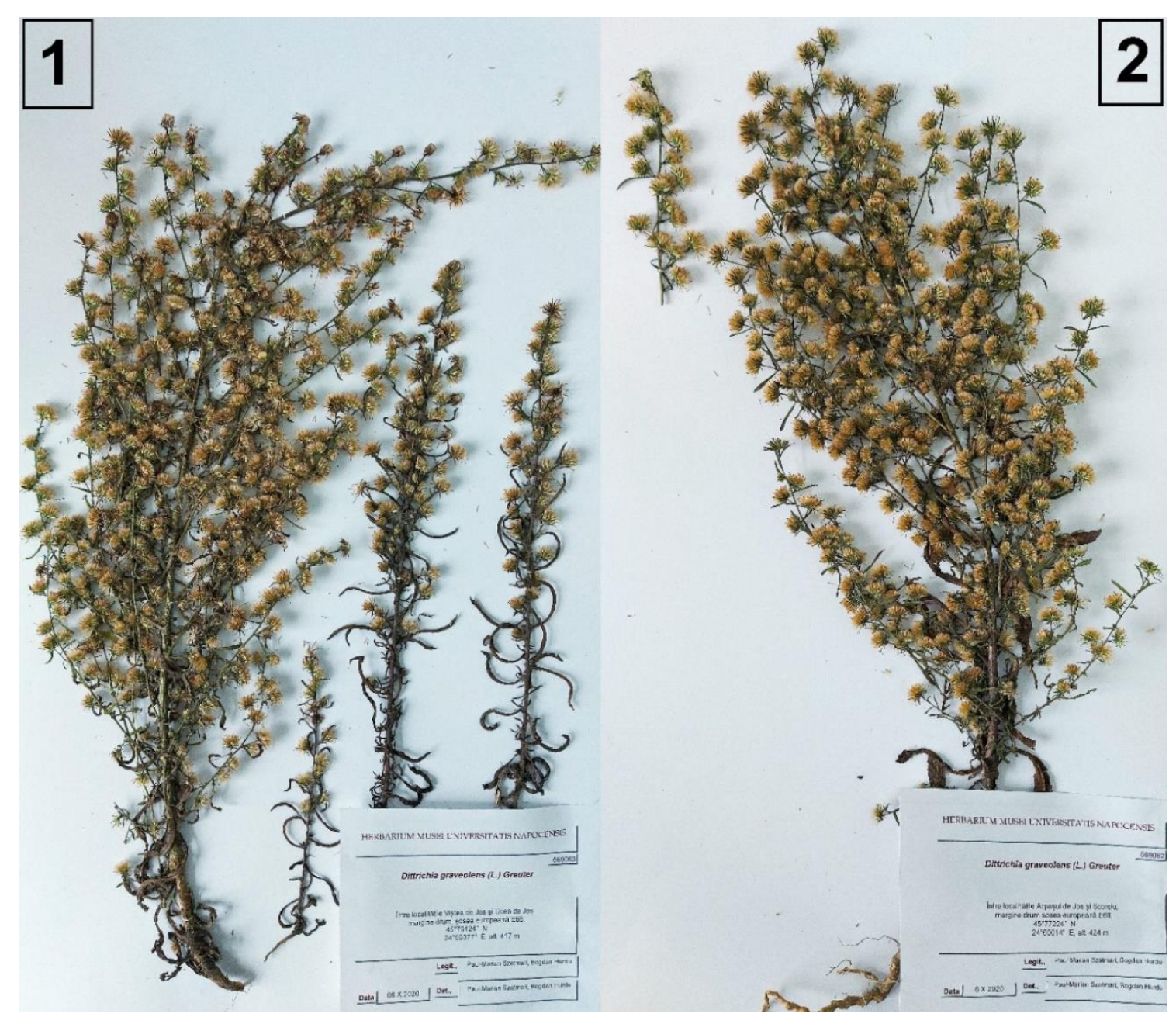

Fig. 1: Specimens of Dittrichia graveolens collected from the two populations in Brașov County (population 1) and Sibiu County (population 2) deposited in the Herbarium of „A. Borza” Botanical Garden, BabeșBolyai University in Cluj-Napoca (CL).

\section{Results and Discussion}

We discovered Dittrichia graveolens in two separate locations at approximately $10 \mathrm{~km}$ apart, along the European road E68 (DN1) connecting Sibiu and Brașov cities, in Southern Transylvania, (Fig. 2), during the field work we carried out in October 2020 for mapping invasive species distribution in Sibiu and Braşov counties. Individuals from the population 1 (Fig. 2) occurred on road verges and in the cracks formed between the concrete tiles of the bridge crossing the river Corbul Ucii, in Brașov County, between the villages Viștea de Jos and Ucea de Jos (N 45.79124 / E 24.69377, $417 \mathrm{~m}$ a.s.1.). This population comprised several hundred individuals spread over $>1000 \mathrm{~m}^{2}$, most found at the fruiting stage or final stage of flowering. The population 2 (Fig. 2), which we evaluated as being much smaller, having fewer than 10 individuals spread over $100 \mathrm{~m}^{2}$, occurred in Sibiu County, approximately $10 \mathrm{~km}$ west from the first record, along the national road (E68/DN1) connecting the villages of Arpaşul de Jos and Scoreiu (N 45.77224 / E 
24.60014, $424 \mathrm{~m}$ a.s.1.). Most individuals from population 2 were still at the flowering stage. Following the observations made in Poland [35], the plants were reported flowering in early autumn (September-October), which mostly corresponds to our findings.

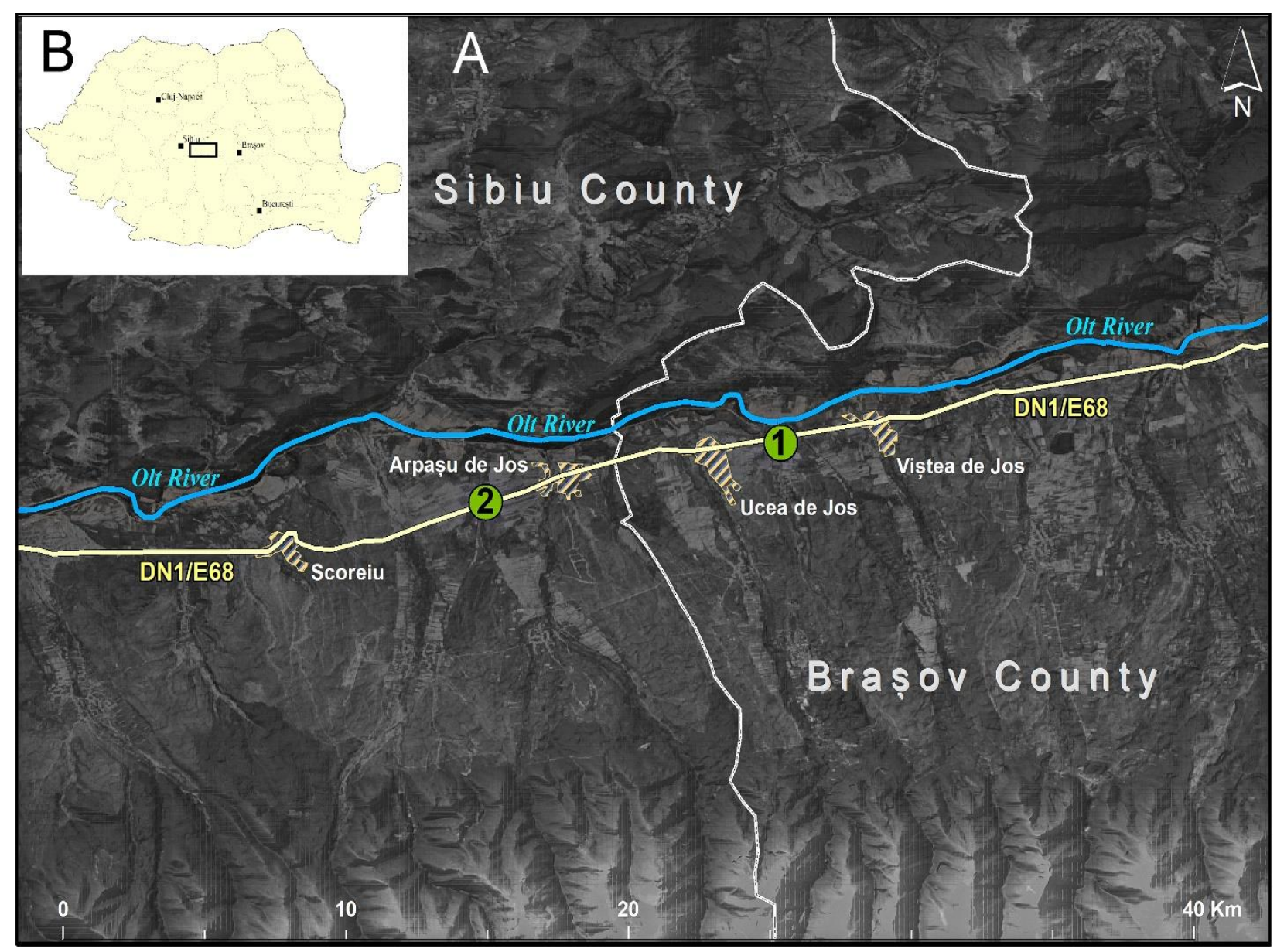

Fig. 2: Map showing (A) the location of the two recorded occurrences of Dittrichia graveolens in Braşov County (population 1, green dot) and Sibiu County (population 2, green dot) and (B) the placement of the investigated area within Romania (indicated by the small black-contoured box)

We found most of the individuals in crevices formed between concrete tiles near bridges and in the immediate vicinity of the European road. Few other species occurred there, notably: Setaria pumila, Digitaria sanguinalis, Atriplex patula, Cichorium intybus or Rubus caesius var. arvalis. The nearby habitats are strongly ruderal, with the Corbul Ucii river banks (Fig. 3) being colonised by Reynoutria japonica, Echinocystis lobata, Amorpha fruticosa, Helianthus tuberosus, Solidago canadensis and Robinia pseudoacacia.

The species has been naturalized in many parts of the world, including Australia, New Zealand, South Africa, Mexico, and the USA, being considered a pest of cereal crops in South Africa, a common weed in New Zealand, and a highly noxious weed in California and Australia (Victoria, Queensland) [46, 8, 16, 10, 3, 14, 34]. In California it can establish itself in riparian floodplains and seasonal wetlands that are mainly disturbed by natural or anthropogenic elements [10]. In Australia it was observed in semi-natural habitats, mostly in rangelands and open woodlands, but also in cereal crops [44]. In both Australia and the USA, Dittrichia graveolens is classified as a high risk invasive species [58]. 
In Europe, Dittrichia graveolens has been recorded as an alien plant species in Austria in 2001 [27, 53], Germany in 2003 [49], Belgium in 2004 [37], The Netherlands [40] and Switzerland [13] in 2005, United Kingdom in 2006 [52], the Czech Republic in 2008 [47, 48], Slovenia in 2009 [22], Slovakia in 2014 [33], Poland in 2015 [35, 45, 36], and Hungary in 2016 [57]. The first records of the species in Central Europe, according to existing studies [33, 35], were made in Germany, Austria and Slovenia. It is presumed that it spread from there to the neighbouring countries, especially eastwards [35, 33], with multiple studies indicating a remarkable speed in the propagation to new areas in Poland [36].

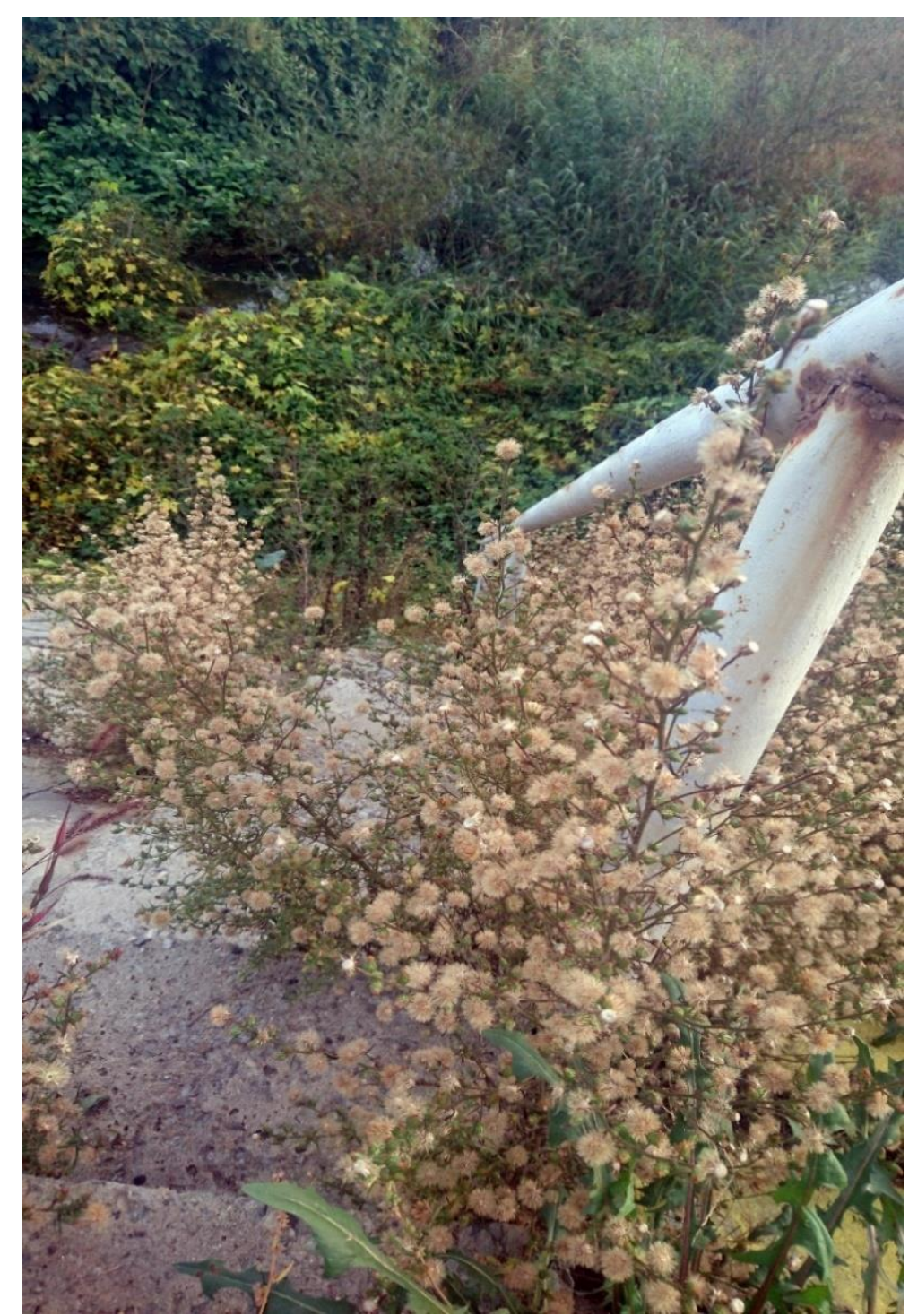

Fig. 3: Dittrichia graveolens (L.) W. Greuter from population 1, near the Corbul Ucii river, along the road that connects Viștea de Jos and Ucea de Jos villages, Brașov County, Romania $\left(6^{\text {th }}\right.$ of October, 2020).

According to Brownsey et al. [10], concerning the native occurrence of Dittrichia graveolens in Southern Europe and its ecological preferences, the species requires sunlit environments and terrain with low vegetation cover, having a highly reduced establishment success in habitats covered by dense vegetation. It has become a problem, however, in low- 
disturbed or arid habitats in similar Mediterranean or semi-arid climates, with scarce vegetation like that found in regions of California or Australia, where the species has rapidly dispersed over extensive areas [14]. Moreover, one plant can produce up to 71.000 seeds that are easily disseminated by wind, water, animals, and by automobiles, being dispersed by the air currents generated by passing vehicles [9], thus making it extremely successful in spreading over long distances in a short time. The seeds can germinate and plants develop in substrates with a wide range of $\mathrm{NaCl}$ concentrations and contaminated with heavy metals or mercury, making it a highly prolific pioneer species that uses the disturbed habitats to expand its areal [23, 26]. Soil salinity is also an important environmental filter that eliminates natural competitors, facilitating the spread and establishment of salt-tolerant Dittrichia graveolens [55]. Being an autumn flowering annual species with a late season development, Dittrichia graveolens is not affected by early-applied herbicide treatments [5]. Further studies carried out in the Spanish Pyrenees concluded that the spread of the species is positively correlated with the use of herbicide glyphosate in the spring, which eliminates competitors and leads to a tabula rasa type of colonisation by Dittrichia graveolens [5].

According to Randall [50] the global invasive risk score rating of this species is low; however it can have a more significant impact in particular ecological situations. Considering its affinities to deteriorated riparian communities, there is a significant possibility that Dittrichia graveolens will establish itself as a common weed in the disturbed habitats along river banks. Consequently, we assess that the species could become a problematic weed especially in SouthWestern, South and South-Eastern Romania, with emphasis on the Danube Valley area and the Dobrogea region, owing to the warmer, sub-Mediterranean climate and long, hot summers characterising these regions. Moreover, most of the protected areas from Romania harbouring continental sand dunes are heavily impacted by invasive species, especially Ambrosia artemisiifolia [54], and the spreading potential of Dittrichia graveolens could create additional pressures on these habitats and their native species. However, the scarcity of studies from Europe concerning the colonizing potential of this species in the continental sand dunes, characterised by scarce vegetation, may offer an incomplete picture of the actual threat posed by Dittrichia graveolens and the appropriate preventive measures to be undertaken in order to control its dispersal within these specific habitats. Following the existing weed pest control knowledge from California, the most effective control method for this species has proven to be the cutting or mowing of stems in September, immediately prior to flowering [10]. Therefore, considering the more frequent occurrence of Dittrichia graveolens in annual grassland communities [10] and disturbed habitats, its distribution in Romania should be further investigated and carefully monitored, while currently known methods of control should be applied.

\section{Conclusion}

We report here the first occurrence of the species Dittrichia graveolens in Romania. Following the currently available data, we consider the newly reported species to be a casual alien plant species in Romania. However, with its proven high invasive potential in other parts of Europe and North America, once established, due to its easy dispersal over long distances along the roadsides and its ample ecological tolerance, it should be treated as a high risk invasive plant and managed accordingly before it spreads in other parts of the country. Currently, we can only 
speculate on the origin of these populations and if these may be considered source populations or if the species is actually more widely distributed locally or in Romania. For this reason, additional field surveys, with more extensive terrain coverage, should be carried out in order to better assess the full extent of this alien species occurrence and its real impact on the natural habitats from our country.

Acknowledgements: We are grateful to Pavel Dan Turtureanu, Paulina Anastasiu, Ioana-Minodora Sîrbu and an anonymous reviewer for their valuable suggestions that helped to improve our manuscript. The fieldwork was realised within the framework and with the financial support received through the national project POIM120008 „Adequate management of invasive species in Romania, in accordance with EU Regulation 1143/2014 on the prevention and management of the introduction and spread of invasive alien species", aimed at collecting all available distribution data regarding the alien flora of Romania.

\section{REFERENCES}

1. Anastasiu, P., Negrean, G., 2005, Alien plants in Romania (I), Analele Şti. Univ. Iaşi, Ser II, Biol. Veg., 51: 87-96.

2. Anastasiu, P., Negrean, G., 2008, New alien plants to Romania, Analele Univ. din Craiova, Seria Agricultură, Montanologie, Cadastru, 38/B: 1-10.

3. Atha, D., Wang, Z., Barron, C., Liljengren, H., 2019, Dittrichia graveolens (Asteraceae) naturalized and invasive in New York State, Phytoneuron, 4: 1-4.

4. Ball, P.W., 1976, Dittrichia Greuter. In: Tutin, T.G., Heywood, V.H., Burges, N.A., Moore, D.M., Valentine, D.H., Walters, S.M., Webb, D.A., Ball P.W. (eds), Flora Europaea 4. Cambridge University Press, Cambridge: $136-137$.

5. Benito Alonso, J.-L., 2016, Expansión de Dittrichia graveolens (L.) Greuter (Asteraceae) por las carreteras del Pirineo y su relación con el uso de glifosato, Flora Montiberica, 64: 29-37.

6. Brandes, D., 2007, Artemisia tournefortiana Reichenb. als neue Autobahn-Pflanze (Artemisia tournefortiana Reichenb. new at highways in Germany), (online) [cit. 31. 10. 2020]. Available from: http://www.digibib.tubs.de/?docid $=00021461$.

7. Brandes, D., 2009, Autobahnen als Wuchsorte und Ausbreitungswege von Ruderal- und Adventivpflanzen, Braunschw. naturkdl. Schr., 8: 373-394.

8. Brownsey, R.N., Kyser, G.B., DiTomaso, J.M., 2013a, Stinkwort is rapidly expanding its range in California, Calif. Agric., 67: 110-115.

9. Brownsey, R.N., Kyser, G.B., DiTomaso, J.M., 2013b, Seed and germination biology of Dittrichia graveolens (Stinkwort), Invasive Plant Science and Management, 6: 371-380.

10. Brownsey, R.N., Kyser, G.B., DiTomaso, J.M., 2013c, Growth and phenology of Dittrichia graveolens, a rapidly spreading invasive plant in California, Biological Invasions, 16: 43-52.

11. Brullo, B., de Marco G., 2000, Taxonomical revision of the genus Dittrichia (Asteraceae), Portugaliae Acta Biol., 19: 341-354.

12. Chen, H., Liu, J., Xue, T., Wang, R.Q., 2011, Roads accelerate the invasion process of alien species, Advanced Materials Research, 347-353: 1483-1487.

13. Ciardo, F., Delarze, R., 2005, Observations floristiques sur l'autoroute lémanique: espèces nouvelles, halophiles et rares, Saussurea; travaux de la société botanique de Genève, Geneva, 35: 83-99.

14. Csurhes, S., Zhou Y., 2008, Pest Plant Risk Assessment. Stinkwort. Dittrichia graveolens, Department of Primary Industries and Fisheries, Queensland, Brisbane.

15. Dar, P.A., Reshi, Z.A., Shah, M.A., 2015, Roads act as corridors for the spread of alien plant species in the mountainous regions: A case study of Kashmir Valley, India, Tropical Ecology, 56 (2): 49-56. 
16. DiTomaso, J. M., 2004, 2004 Cal-IPC Red Alert! New invasions, recent expansions, and a few others to be on the look-out for...., Pages 139-141. In: C. Pirosko, (ed.), Proceedings of the California Invasive Plant Council Symposium (Vol. 8: 2004), California Invasive Plant Council, Berkely, CA, U.S.A.

17. ESRI, 1999-2009, ArcGIS: Release 9.3, Redlands, Redlands, CA: Environmental Systems Research Institute.

18. Essl, F., Dullinger, S., Kleinbauer, I., 2009, Changes in the spatio-temporal patterns and habitat preferences of Ambrosia artemisiifolia during its invasion of Austria, Preslia, 81: 119-133.

19. Fekete, R., Mesterházy, A., Valkó, O., Molnár, A.V., 2018, A hitchhiker from the beach: the spread of the maritime halophyte Cochlearia danica along salted continental roads, Preslia, 90: 23-37.

20. Fernandez-Murillo, M. P., Rico, A., Kindlmann, P., 2015, Exotic plants along roads near La Paz, Bolivia, Weed Research, 55 (6): 565-573.

21. Follak, S., Eberius, M., Essl, F., Fürdös, A.,Sedlacek, N., Trognitz, F., 2018, Invasive alien plants along roadsides in Europe, EPPO Bulletin, 0: 1-10.

22. Frajman, B., Kaligarič, M., 2009, Dittrichia graveolens, nova tujerodna vrsta slovenske flore (Dittrichia graveolens, a new alien species of the Slovenian flora), Hladnikia, 24: 35-43.

23. Grašič, M., Anžlovar, S., Strgulc Krajšek, S., 2016, Germination rate of stinkwort (Dittrichia graveolens) and false yellowhead (D. viscosa) in relation to salinity, Acta Biologica Slovenica, 59: 5-11.

24. Greuter, W., von Raab-Straube, E., 2020, Compositae. Dittrichia graveolens, Euro+Med (2006-): Euro+Med PlantBase - the information resource for Euro-Mediterranean plant diversity, Published on the Internet http://ww2.bgbm.org/EuroPlusMed/ [accessed 31.10.2020].

25. Griese, D., 1998, Die viatische Migration einiger neophytischer Pflanzensippen am Beispiel norddeutscher Autobahnen, Braunschw. Geobot. Arb., 5: 263-270.

26. Higueras, P., Oyarzum, R., Biester, H., Lillo, J., Lorenzo, S., 2003, A first insight into mercury distribution and speciation in the Almadén mining district, Spain, Journal of Geochemical Exploration, 80: 95-104.

27. Hohla, M., 2001, Dittrichia graveolens (L.) Greuter, Juncus ensifolius Wikstr. und Ranunculus penicillatus (Dumort.) Bab. neu fur Osterreich und weitere Beitrage zur Kenntnis der Flora des Innviertels und des angrenzenden Bayerns, Beitr. Naturk. Oberösterreichs, 10: 275-353.

28. Hohla, M., Raabe, U., 2012, Cochlearia danica - das Dänische Löffelkraut - kein überraschender Neuzugang der Flora von Oberösterreich, Stapfia, 97: 206-209.

29. Horvitz, N, Wang, R, Wan, F-H, Nathan, R., 2017, Pervasive human-mediated large-scale invasion: analysis of spread patterns and their underlying mechanisms in 17 of China's worst invasive plants, Journal of Ecology, 105: 85-94.

30. Ianovici, N., 2011, Approaches on the invasive alien taxa in Romania - Ambrosia artemisiifolia (ragweed) II, Annals of West University of Timişoara, ser. Biology, 14: 93-112.

31. Jodoin, Y., Lavoie, C., Villeneuve, P., Theriault, M., Beaulieu, J., Belzile, F., 2008, Highways as corridors and habitats for the invasive common reed Phragmites australis in Quebec, Canada, Journal of Applied Ecology, 45: $459-466$.

32. Joly, M., Bertrand, P., Gbangou, R.Y., White, M.-C., Dubé, J., Lavoie, C., 2011, Paving the way for invasive species: road type and the spread of common ragweed (Ambrosia artemisiifolia), Environmental Management, 48: $514-522$.

33. Király, G., Eliáš, P. jun., Dítě, D., 2014, Two thermophilic alien species new to the flora of Slovakia, Thaiszia - J. Bot., 24: 125-134.

34. Kloot, P. M., 1987, The naturalised flora of South Australia 4. Its manner of introduction, J. Adelaide Bot. Gard., 10 (2): 223-240.

35. Kocián, P., 2015, Dittrichia graveolens (L.) Greuter - a new alien species in Poland, Acta Mus. Siles. Sci. Natur., 64: 193-197.

36. Kozłowska-Kozak, K., Kozak, M., Pliszko, A., 2019, Fast spread of Dittrichia graveolens (Asteraceae) in southwestern Poland, Botanica, 25 (1): 84-88.

37. Lambinon, J., Delvosalle, L., Duvigneaud, J., 2004, Nouvelle Flore de la Belgique, du Grand-Duché de Luxembourg, du Nord de la France et des régions voisines, Ed. 5 (Edition du Patrimoine du Jardin botanique national de Belgique), Meise.

38. Lelong, B., Lavoie, C., Jodoin, C., Belzile, F., 2007, Expansion pathways of the exotic common reed (Phragmites australis): a historical and genetic analysis, Diversity and Distributions, 13: 430-437. 
39. Lemke, A, Kowarik, I, von der Lippe, M., 2019, How traffic facilitates population expansion of invasive species along roads: The case of common ragweed in Germany, Journal of Applied Ecology, 56: 413-422.

40. Meijden, R. van der, 2005, Heukels' Flora van Nederland, Ed. 23, Wolters-Noordhoff, Groningen.

41. Melzer, H., 2003, Sporobolus vaginiflorus (Poaceae), ein Neubürger aus Nordamerika, lange übersehen in Österreich - und anderes Neue zur Flora von Kärnten, Neilreichia, 2-3: 131-142.

42. Meusel, H., Jäger E., 1992, Vergleichende Chorologie der zentraleuropäischen Flora 3. Gustav Fischer Verlag, Jena, Stuttgart, New York.

43. Parolin, P., Scotta, M.I., Bresch, C., 2014, Biology of Dittrichia viscosa, a Mediterranean ruderal plant: a review (Biología de Dittrichia viscosa, una planta ruderal del Mediterráneo: revision), FYTON, 83: 251-262.

44. Parsons, W. T., Cuthbertson, E. G., 1992, Noxious weeds of Australia, Inkata Press, Melbourne - Sydney.

45. Pliszko, A., Kocián, P., 2017, Further notes on the distribution of Dittrichia graveolens (Asteraceae) in Poland, Acta Mus. Siles. Sci. Natur., 66: 259-262.

46. Preston, R.E., 1997, Dittrichia graveolens (Asteraceae), new to the California weed flora, Madroño, 44 (2): 200-203.

47. Raabe, U., 2008, Dittrichia graveolens. In: Fischer, M., Niklfeld, H., (eds): Floristische Neufunde (76- 98), Neilreichia, 5: 270-271.

48. Raabe, U., 2009, Dittrichia graveolens (L.) Greuter. In: Hadinec, J., Lustyk, P., (eds): Additamenta ad floram Reipublicae Bohemicae, VIII, Zpr. Čes. Bot. Spol., 44: 235-238.

49. Radkowitsch, A., 2003, Neophytic plants in Bavaria (Senecio inaequidens and Dittrichia graveolens), pp. 4761, In: Zając, A., Zając, M., Zemanek, B., (eds): Phytogeographical problems of synanthropic plants, Institute of Botany, Jagiellonian University, Kraków.

50. Randall, R. P., 2017, A Global Compendium of Weeds. 3rd Edition, Perth, Western Australia, R. P. Randall.

51. Rauschert, E.S.J, Mortensen, D.A, Bloser, S.M., 2017, Human-mediated dispersal via rural road maintenance can move invasive propagules, Biological Invasions, 19: 2047-2058.

52. Sell, P., Murrell, G., 2006, Flora of Great Britain and Ireland 4, Cambridge University Press, Cambridge.

53. Stöhr, O., Pilsl, P., Essl, F., Wittmann, H., Hohla, M., 2009, Beiträge zur Flora von Österreich, III, Linzer biol. Beitr., 41: 1677-1755.

54. Szatmari, P.-M., 2012, Alien and invasive plants in Carei Plain natural protected area, western Romania: Impact on natural habitats and conservation implications, South Western Journal of Horticulture, Biology and Environment, 3: 109-120.

55. Šajna, N., Adamlje, K., Kaligarič, M., 2017, Dittrichia graveolens - How does soil salinity determine distribution, morphology, and reproductive potential?, Annales. Ser. hist. nat., 27 (1): 7-12.

56. Šerá, B., 2008, Road vegetation in Central Europe - an example from the Czech Republic, Biologia, 63: 10851088.

57. Takács, A., Baráth, K., Csiky, J., Csikyné, E-R., Király, G., Nagy, T., Papp, V., Schmidt, D., Tamási, B., Barina, Z., 2016, Taxonomical and chorological notes 3 (28-37), Studia Bot. Hung., 47 (2): 345-357.

58. USDA, United States Department of Agriculture, 2013, Weed Risk Assessment for Dittrichia graveolens (L.) Greuter (Asteraceae) - Stinkwort, Plant Epidemiology and Risk Analysis Laboratory, Center for Plant Health Science and Technology, Plant Protection and Quarantine, Animal and Plant Health Inspection Service, United States Department of Agriculture, 1730 Varsity Drive, Suite 300, Raleigh, NC 27606.

59. Wróbel, A., Nobis, N., 2017, Spread of Eragrostis albensis (Poaceae) and Dittrichia graveolens (Asteraceae) in the southern Poland, Acta Mus. Siles. Sci. Natur., 66: 117-120.

60. Zimmermann, H., Loos, J., von Wehrden, H., Fischer, J., 2015, Aliens in Transylvania: risk maps of invasive alien plant species in central Romania, NeoBiota, 24: 55-65.

\section{DITTRICHIA GRAVEOLENS (ASTERACEAE) - O NOUĂ SPECIE INVAZIVĂ ÎN ROMÂNIA}

\section{(Rezumat)}

Dittrichia graveolens (L.) W. Greuter, o specie invazivă de origine mediteraneeană, este raportată pentru prima oară din România. Am descoperit specia în octombrie 2020 în două localități separate de-a lungul șoselei 
principale ce leagă orașele Braşov și Sibiu din sudul Transilvaniei, regiunea centrală a României. Prezentăm primele date asupra prezenței speciei în zona investigată, a habitatului în care a fost observată, a distribuției locale și a speciilor însoțitoare. Presupunem că principalul factor ce a condus la introducerea și răspândirea speciei este legat de traficul auto ridicat de-a lungul şoselelor principale. Potențialul invaziv ridicat al speciei Dittrichia graveolens a fost demonstrat în alte regiuni din Europa şi America de Nord caracterizate prin condiții climatice asemănătoare celor din țara noastră, de tip temperat. În consecință, luând în considerare capacitatea mare de dispersie a speciei, îndeosebi în habitatele ce favorizează naturalizarea ei, prezente la altitudini joase de-a lungul marilor artere de transport și al coridoarelor ripariene din vestul, sudul și estul României, considerăm necesară monitorizarea atentă a prezenței acesteia pentru a estima mai precis distribuția ei completă în țara noastră și pentru a reduce impactul ei asupra comunităților naturale de plante.

Received: 11.12.2020; Accepted: 21.12.2020 